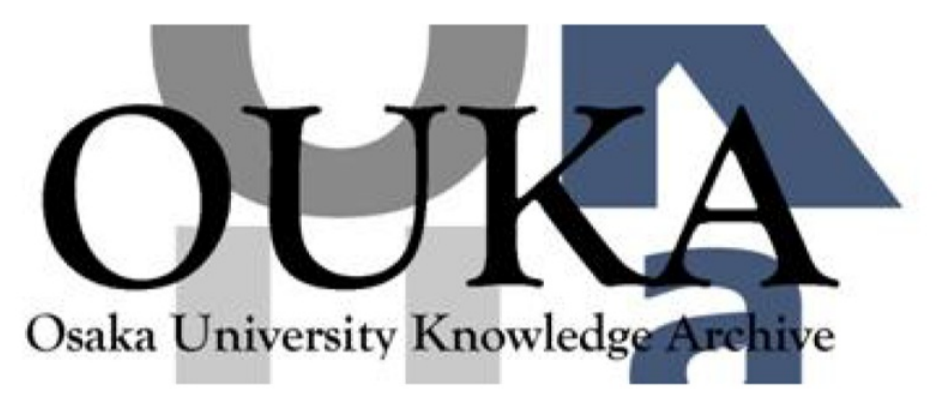

\begin{tabular}{|c|l|}
\hline Title & $\begin{array}{l}\text { Synthesis and Properties of Dinitromethylated } \\
\text { Arenes. Reinvestigation of the Ponzio Reaction }\end{array}$ \\
\hline Author(s) & $\begin{array}{l}\text { Suzuki, Hitomi; Takaoka, Hiroshi; Yamamoto, } \\
\text { Hidetoshi }\end{array}$ \\
\hline Citation & $\begin{array}{l}\text { BULLETIN OF THE CHEMICAL SOCIETY OF JAPAN. } \\
61(8) \text { p. 2927-p. 2931 }\end{array}$ \\
\hline Issue Date & $1988-08$ \\
\hline oaire:version & VoR \\
\hline URL & https://hdl. handle.net/11094/3443 \\
\hline rights & \\
\hline Note & \\
\hline
\end{tabular}

Osaka University Knowledge Archive : OUKA

https://ir. Library. osaka-u. ac. jp/

Osaka University 


\title{
Synthesis and Properties of Dinitromethylated Arenes. Reinvestigation of the Ponzio Reaction ${ }^{1)}$
}

\author{
Hitomi Suzuki, * Hiroshi Takaoka, Hidetoshi Yamamoto, and Takuji Ogawa \\ Department of Chemistry, Faculty of Science, Ehime University, Bunkyo-cho, Matsuyama 790
}

(Received March 22, 1988)

Several title compounds have been prepared by the modified Ponzio procedure and their IR, ${ }^{1} \mathbf{H}$ and ${ }^{13} \mathrm{C}$ NMR data are presented. In some cases trinitromethylated arenes were obtained as a by-product. Oxidative cleavage to parent aldehydes and oxidation to carboxylic acids were the major competing reactions. 9Anthracenecarbaldehyde oxime and 10-methyl-9-anthracenecarbaldehyde oxime reacted with nitrogen dioxide in an unexpected way, giving 10-nitro-9-anthracenecarbonitrile oxide and 10-methyl-10-nitro-9-anthrone as the respective main products. Nitration of (dinitromethyl)benzene has also been examined under various conditions.

In a previous paper, ${ }^{2)}$ we reported that the action of concentrated nitric acid on 9-methyl-9-nitro-10-nitromethylene-9,10-dihydroanthracene led to 9-methyl-10trinitromethylanthracene as one of the main products. Contrary to our expectation, 9-dinitromethyl-10methylanthracene could not be detected in the product mixture. This unexpected result made us necessary to investigate the behavior of dinitromethylated arenes toward nitric acid. Search for relevant literature revealed that there are only several scattered papers which describe the preparation and properties of (dinitromethyl)arenes. ${ }^{3-9)}$ The sole general method for the direct preparation of this type of compounds is that first reported by Ponzio, who converted benzaldehyde oxime (la) into (dinitromethyl)benzene (2a) by the action of nitrogen dioxide in ether. ${ }^{3,4)}$<smiles></smiles>

$\underline{1}$
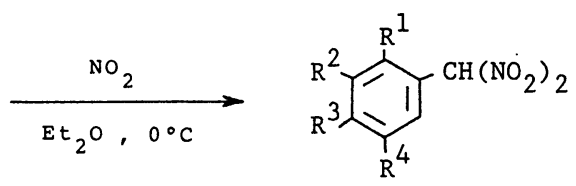

$\underline{2}$

$\begin{array}{lllll} & \mathrm{R}^{1} & \mathrm{R}^{2} & \mathrm{R}^{3} & \mathrm{R}^{4} \\ \mathrm{a} & \mathrm{H} & \mathrm{H} & \mathrm{H} & \mathrm{H} \\ \mathrm{b} & \mathrm{H} & \mathrm{H} & \mathrm{Me} & \mathrm{H} \\ \mathrm{c} & \mathrm{MeO} & \mathrm{H} & \mathrm{H} & \mathrm{H} \\ \mathrm{d} & \mathrm{H} & \mathrm{H} & \mathrm{MeO} & \mathrm{H} \\ \mathrm{e} & \mathrm{MeO} & \mathrm{H} & \mathrm{H} & \mathrm{MeO} \\ \mathrm{f} & \mathrm{H} & \mathrm{H} & \mathrm{Cl} & \mathrm{H} \\ \mathrm{g} & \mathrm{H} & \mathrm{NO}_{2} & \mathrm{H} & \mathrm{H} \\ \mathrm{h} & \mathrm{H} & \mathrm{H}^{-} & \mathrm{NO}_{2} & \mathrm{H} \\ \mathrm{i} & -(\mathrm{CH}=\mathrm{CH})_{2}^{-} & \mathrm{H} & \mathrm{H} \\ \mathrm{j} & -(\mathrm{CH}=\mathrm{CH})_{2}^{-} & \mathrm{Me} & \mathrm{H}\end{array}$

In order to obtain $\mathbf{2 a}$ in some quantity, we initially tried to carry out the Ponzio reaction of aldoxime la according to the original conditions given in the literature. However, to our disappointment, duplication proved to be quite unsatisfactory; the yields of $\mathbf{2 a}$ were always lower, the major product being benzoic acid. We have therefore undertook a systematic study to find the optimum conditions to obtain $\mathbf{2 a}$ in acceptable yields.

Bubbling of nitrogen dioxide gas into an ice-cooled solution of $1 \mathrm{a}$ in ether, followed by quenching with water and extraction with aqueous sodium hydrogencarbonate led to little or no dinitromethyl compound. Dropwise addition of an ethereal solution of la to a solution of 2 equiv of nitrogen dioxide in the same solvent gave the desired product only in a low yield. Increase in amount of nitrogen dioxide from 2 to 5 equiv improved the yield of $\mathbf{2 a}$ appreciably, but the benzoic acid was the main product as yet. To our satisfaction, acceptable results were obtained with good reproducibility when the reaction of $\mathbf{l a}$ was allowed to proceed in the presence of 10 equiv of nitrogen dioxide and the solvent was removed under reduced pressure immediately after complete disappearance of la on TLC plate. Aqueous work-up of the reaction mixture as described in the literature led to poor results.

Using the optimized conditions defined above, a series of substituted benzaldehyde oximes $\mathbf{l b}-\mathbf{l h}$ and $\mathbf{1 -}$ naphthaldehyde oximes $\mathbf{l i}-\mathbf{l j}$ were converted into the corresponding dinitromethylated arenes $\mathbf{2} \mathbf{b}-\mathbf{2} \mathbf{j}$, the yields and physical properties of which are presented in Table 1. No spectral data of these appear to have been reported previously in the literature. (Dinitromethyl)arenes are colorless crystals which can be stored indefinitely under the exclusion of light and moisture. They are readily soluble in dichloromethane, chloroform, carbon tetrachloride, benzene, ethanol, and ether; fairly soluble in hot hexane, and slightly soluble in cold hexane. They melt without decomposition.

In some cases trinitromethylated compounds were obtained as the minor product. These compounds are thermally unstable and on heating readily decompose under the evolution of nitrogen oxides to afford arenecarboxylic anhydride. ${ }^{10)}$ In contrast to (dinitromethyl)arenes which appear as a yellow spot on TLC and 
Table 1. (Dinitromethyl)arenes Obtained

\begin{tabular}{|c|c|c|c|c|c|c|c|c|c|c|c|}
\hline & \multicolumn{4}{|c|}{ (Dinitromethyl)arene 2} & \multirow{2}{*}{$\begin{array}{c}\mathrm{Mp} \\
\left(\theta_{\mathrm{m}} /{ }^{\circ} \mathrm{C}\right)\end{array}$} & \multirow{2}{*}{$\frac{\text { Yield }}{\%}$} & \multirow{2}{*}{$\frac{\mathrm{IR}(\mathrm{KBr})}{\mathrm{cm}^{-1}}$} & \multirow{2}{*}{$\begin{array}{c}{ }^{1} \mathrm{H} \text { NMR } \\
\left(\mathrm{CDCl}_{3} / \mathrm{TMS}\right) \\
\delta / \mathrm{ppm}\end{array}$} & \multirow{2}{*}{$\begin{array}{c}{ }^{13} \mathrm{C} \text { NMR } \\
\left(\mathrm{CDCl}_{3} / \mathrm{TMS}\right) \\
\delta / \mathrm{ppm}\end{array}$} & \multicolumn{2}{|c|}{$\begin{array}{l}\text { Elementary } \\
\text { analysis/\% }\end{array}$} \\
\hline & $\mathbf{R}^{1}$ & $\mathbf{R}^{2}$ & $\mathbf{R}^{3}$ & $\mathbf{R}^{4}$ & & & & & & Found & Calcd \\
\hline $\mathbf{a}$ & $\mathbf{H}$ & $\mathbf{H}$ & $\mathbf{H}$ & $\mathbf{H}$ & $\begin{array}{c}79-80 \\
\left(\text { lit, }{ }^{6)} 78-80\right)\end{array}$ & 41 & $\begin{array}{l}1540,1360,1320 \\
1290,805,710 \\
680\end{array}$ & $\begin{array}{l}7.10(\mathrm{~s}, 1 \mathrm{H}), 7.48- \\
7.61(\mathrm{~m}, 5 \mathrm{H})\end{array}$ & $\begin{array}{l}133.0,129.6,129.5 \\
125.3,112.4\end{array}$ & - & - \\
\hline b & $\mathbf{H}$ & $\mathbf{H}$ & $\mathrm{Me}$ & $\mathbf{H}$ & $78-80$ & 47 & $\begin{array}{l}1590,1560,1375 \\
1330,820,755\end{array}$ & $\begin{array}{l}2.38(\mathrm{~s}, 3 \mathrm{H}), 7.07 \\
(\mathrm{~s}, 1 \mathrm{H}), 7.29(\mathrm{~d}, \\
2 \mathrm{H} ; J=8.2 \mathrm{~Hz}), 7.44 \\
(\mathrm{~d}, 2 \mathrm{H} ; J=8.2 \mathrm{~Hz})\end{array}$ & $\begin{array}{l}143.9,130.0,129.5 \\
122.3,112.5,21.24\end{array}$ & 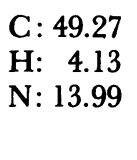 & $\begin{array}{r}48.98 \\
4.11 \\
14.28\end{array}$ \\
\hline c & $\mathrm{MeO}$ & $\mathbf{H}$ & $\mathbf{H}$ & $\mathbf{H}$ & $48-50$ & 36 & $\begin{array}{l}1570,1495,1470, \\
1440,1375,1330, \\
1300,1260,1190, \\
1170,1115,1055, \\
1030,825,760, \\
715\end{array}$ & $\begin{array}{l}3.90(\mathrm{~s}, 3 \mathrm{H}), 7.00- \\
7.13(\mathrm{~m}, 2 \mathrm{H}), 7.39- \\
7.41(\mathrm{~m}, \mathrm{lH}), 7.54- \\
7.58(\mathrm{~m}, \mathrm{lH}), 7.60 \\
(\mathrm{~s}, 1 \mathrm{H})\end{array}$ & $\begin{array}{l}158.1,134.4,128.8, \\
121.4,114.3,111.3, \\
108.1,56.03\end{array}$ & 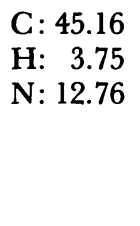 & $\begin{array}{r}45.29 \\
3.80 \\
13.20\end{array}$ \\
\hline d & $\mathbf{H}$ & $\mathbf{H}$ & $\mathrm{MeO}$ & $\mathbf{H}$ & $30-32$ & 39 & $\begin{array}{l}1560,1370,1330 \\
1255,1170,1020 \\
815,755\end{array}$ & $\begin{array}{l}3.87(\mathrm{~s}, 3 \mathrm{H}), 7.02 \\
(\mathrm{~d}, 2 \mathrm{H} ; J=8.9 \mathrm{~Hz}), \\
7.03(\mathrm{~s}, 1 \mathrm{H}), 7.53 \\
(\mathrm{~d}, 2 \mathrm{H} ; J=8.9 \mathrm{~Hz})\end{array}$ & $\begin{array}{l}163.2,131.5,117.2 \\
114.9,112.6,55.55\end{array}$ & 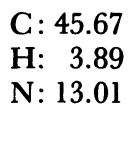 & $\begin{array}{r}45.29 \\
3.80 \\
13.20\end{array}$ \\
\hline e & $\mathrm{MeO}$ & $\mathbf{H}$ & $\mathbf{H}$ & $\mathrm{MeO}$ & $41-42$ & 37 & $\begin{array}{l}1570,1505,1460 \\
1330,1235,1040 \\
830,800,765\end{array}$ & $\begin{array}{l}3.76(\mathrm{~s}, 3 \mathrm{H}), 3.83 \\
(\mathrm{~s}, 3 \mathrm{H}), 6.92(\mathrm{~d}, \\
1 \mathrm{H} ; J=3.0 \mathrm{~Hz}), 6.95 \\
\left(\mathrm{~d}, 1 \mathrm{H} ; J^{\prime}=9.2 \mathrm{~Hz}\right) \\
7.10(\mathrm{dd}, 1 \mathrm{H} ; J= \\
\left.3.0 \mathrm{~Hz}, J^{\prime}=9.2 \mathrm{~Hz}\right) \\
7.61(\mathrm{~s}, 1 \mathrm{H})\end{array}$ & $\begin{array}{l}153.7,152.3,119.8 \\
114.2,113.6,112.5, \\
107.8,56.27,56.23\end{array}$ & 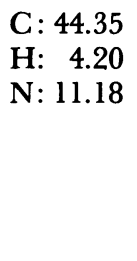 & $\begin{array}{r}44.63 \\
4.16 \\
11.57\end{array}$ \\
\hline f & $\mathrm{H}$ & $\mathbf{H}$ & $\mathrm{Cl}$ & $\mathbf{H}$ & $52-53$ & 48 & $\begin{array}{l}1575,1550,1480 \\
1360,1320,1080 \\
800,740\end{array}$ & $\begin{array}{l}7.08(\mathrm{~s}, 1 \mathrm{H}), 7.53 \\
(\mathrm{~d}, 2 \mathrm{H} ; J=9.2 \mathrm{~Hz}), \\
7.55(\mathrm{~d}, 2 \mathrm{H} ; J=9.2 \\
\mathrm{Hz})\end{array}$ & $\begin{array}{l}\text { 139.9, 131.1, 129.9, } \\
123.6,111.7\end{array}$ & $\begin{array}{l}\mathrm{C}: 39.07 \\
\mathrm{H}: 2.16 \\
\mathrm{~N}: 12.56\end{array}$ & $\begin{array}{r}38.82 \\
2.33 \\
12.93\end{array}$ \\
\hline g & $\mathrm{H}$ & $\mathrm{NO}_{2}$ & $\mathbf{H}$ & & $\begin{array}{c}122-124 \\
\left.\text { lit, }^{7)} 127-129\right)\end{array}$ & 42 & $\begin{array}{l}1595,1565,1530 \\
1345,1330,720\end{array}$ & $\begin{array}{l}7.23(\mathrm{~s}, 1 \mathrm{H}), 7.77- \\
7.85(\mathrm{~m}, 1 \mathrm{H}), 7.99- \\
8.02(\mathrm{~m}, 1 \mathrm{H}), 8.51- \\
8.56(\mathrm{~m}, 2 \mathrm{H})\end{array}$ & $\begin{array}{l}148.5,135.3,131.0, \\
127.8,126.9,125.3, \\
110.7\end{array}$ & $\begin{array}{l}\mathrm{C}: 37.20 \\
\mathrm{H}: \quad 2.07 \\
\mathrm{~N}: 18.47\end{array}$ & $\begin{array}{r}37.02 \\
2.22 \\
18.50\end{array}$ \\
\hline h & $\mathrm{H}$ & $\mathrm{H}$ & $\mathrm{NO}_{2}$ & $\mathbf{H}$ & $72-74$ & 44 & $\begin{array}{l}1565,1525,1345 \\
1325,845,815 \\
720\end{array}$ & $\begin{array}{l}7.27(\mathrm{~s}, 1 \mathrm{H}), 7.87 \\
(\mathrm{~d}, 2 \mathrm{H} ; J=8.7 \mathrm{~Hz}) \\
8.42(\mathrm{~d}, 2 \mathrm{H} ; J=8.7 \\
\mathrm{Hz})\end{array}$ & $\begin{array}{l}150.5,131.2,130.8 \\
124.6,110.7\end{array}$ & $\begin{array}{l}C: 37.23 \\
H: \quad 2.19 \\
N: 17.98\end{array}$ & $\begin{array}{r}37.02 \\
2.22 \\
18.50\end{array}$ \\
\hline $\mathrm{i}$ & $-(\mathrm{CH}=\mathrm{C}$ & $\mathrm{CH})_{2^{-}}$ & $\mathbf{H}$ & $\mathbf{H}$ & $84-85$ & 50 & $\begin{array}{l}1595,1565,1370 \\
1330,1250,780\end{array}$ & $\begin{array}{l}7.53-7.70(\mathrm{~m}, 4 \mathrm{H}), \\
7.78-7.81(\mathrm{~m}, 1 \mathrm{H}), \\
7.92(\mathrm{~s}, \mathrm{lH}), 7.93- \\
7.97(\mathrm{~m}, 1 \mathrm{H}), 8.06- \\
8.09(\mathrm{~m}, 1 \mathrm{H})\end{array}$ & $\begin{array}{l}133.7,133.6,130.7, \\
129.6,128.7,128.3, \\
127.1,125.1,121.3 \text {, } \\
120.7,110.6\end{array}$ & $\begin{array}{l}\text { C: } 57.23 \\
H: \quad 3.33 \\
N: 12.46\end{array}$ & $\begin{array}{r}56.90 \\
3.47 \\
12.07\end{array}$ \\
\hline $\mathrm{j}$ & $-(\mathrm{CH}=\mathrm{C}$ & $\mathrm{CH})_{2-}$ & $\mathrm{Me}$ & $\mathbf{H}$ & $107-110$ & 28 & $\begin{array}{l}1585,1565,1380 \\
1360,1330,1250, \\
805,775,755\end{array}$ & $\begin{array}{l}2.75(\mathrm{~s}, 3 \mathrm{H}), 7.43 \\
(\mathrm{~d}, 1 \mathrm{H} ; J=7.7 \mathrm{~Hz}) \\
7.58(\mathrm{~d}, 1 \mathrm{H} ; J=7.7 \\
\mathrm{Hz}), 7.61-7.68(\mathrm{~m}, \\
2 \mathrm{H}), 7.77-7.82(\mathrm{~m}, \\
1 \mathrm{H}), 7.89(\mathrm{~s}, 1 \mathrm{H}) \\
8.11-8.14(\mathrm{~m}, 1 \mathrm{H})\end{array}$ & $\begin{array}{l}141.0,132.8,130.7 \\
128.3,128.1,126.9 \\
126.1,125.7,121.2 \\
119.6,110.9,19.96\end{array}$ & $\begin{array}{l}\mathrm{C}: 58.30 \\
\mathrm{H}: \quad 4.07 \\
\mathrm{~N}: 10.88\end{array}$ & $\begin{array}{r}58.54 \\
4.09 \\
11.38\end{array}$ \\
\hline
\end{tabular}

move slowly, (trinitromethyl)arenes are colorless on TLC, run fast, and could be examined only in ultraviolet light. Trinitromethyl group is characterized by its very intense antisymmetric vibration of the nitro groups, which appears as split infrared bands at around $1600 \mathrm{~cm}^{-1}$.

Quite perplexing results were obtained when 9- anthracenecarbaldehyde oxime $(3 ; \mathrm{R}=\mathrm{H})$ and 10methyl-9-anthracenecarbaldehyde oxime $(3 ; \mathrm{R}=\mathrm{Me})$ were subjected to the conditions of the Ponzio reaction. The former compound gave 10-nitro-9-anthracenecarbonitrile oxide ( 7 ) as the major product together with 9-anthracenecarboxylic acid as a by-product, whereas the latter compound produced mainly 10-methyl-10- 


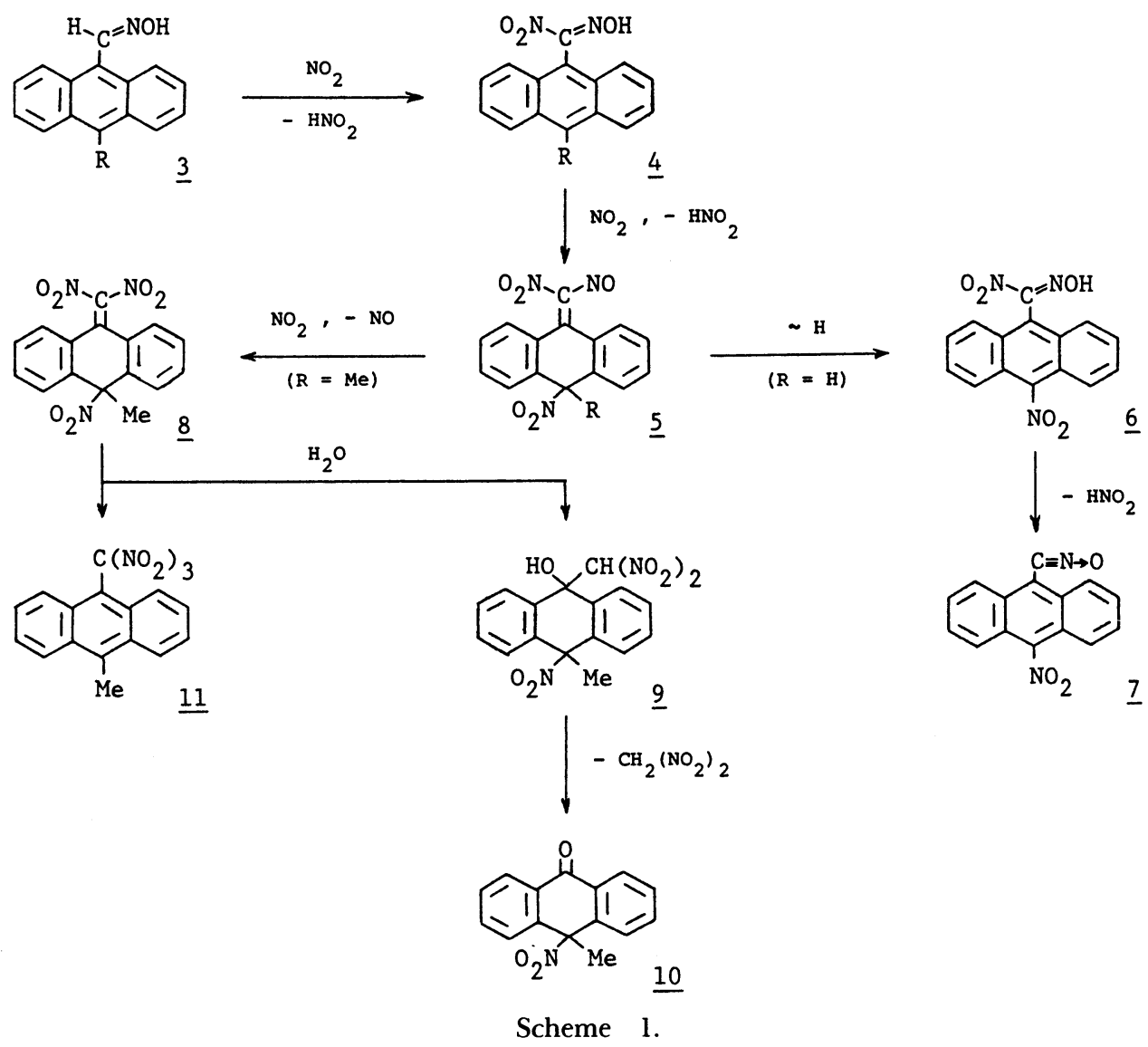

nitro-9-anthrone (10), 9-methyl-10-trinitromethylanthracene (11) being the minor product. Anomalous results observed in the anthracene system pose an interesting problem, a possible solution to which is outlined in Scheme 1.

Abstraction of the oxime hydrogen from 4 followed by attachment of nitrogen dioxide at the meso position leads to the triene intermediate 5 . When $R$ in 5 is hydrogen atom, a facile aromatization would ensue to form the oxime 6, which loses nitrous acid to give the nitrile oxide 7. ${ }^{11)}$ When $\mathbf{R}$ in $\mathbf{5}$ is methyl group, oxidation of nitroso group to nitro group would occur in preference to aromatization to produce the triene $\mathbf{8}$, which either undergoes hydration to form carbinol 9 or isomerizes to 11 possibly via homolytic fission of the carbon-nitrogen bond at the quaternary carbon atom. The carbinol 9 would suffer the retro nitro-aldol reaction to be cleaved into ketone $\mathbf{1 0}$ and dinitromethane.

When (dinitromethyl)benzene 2a was treated with fuming nitric acid $(d=1.5)$ or mixed acid at $-20-$ $-10^{\circ} \mathrm{C}$ for a few hours, there was obtained $m$ nitrophenyldinitromethane $(\mathbf{2 g})$ as the sole product in accord with the literature report. ${ }^{7)}$ Neither the formation of trinitromethylated arenes nor the anomalous reaction similar to that observed during the nitration of (dicyanomethyl)arenes took place under the conditions employed. ${ }^{12)}$ However, when a mixture of $2 a$ and fuming nitric acid was allowed to stand for several days at room temperature, the initially formed $\mathbf{2 g}$ slowly underwent further nitration on the alkyl sidechain to afford $m$-nitrophenyltrinitromethane (12) as the main product. $m$-Nitrobenzoic acid was a side product. In contrast to Titov's claim, ${ }^{7}$ no para substitution products could be obtained.

\section{Experimental}

All melting points were determined on a hot stage apparatus and are uncorrected. Infrared spectra were run as $\mathrm{KBr}$ pellets on a Hitachi 260-10 spectrophotometer and only prominent peaks are recorded. ${ }^{1} \mathrm{H}$ and ${ }^{13} \mathrm{C}$ NMR spectra were obtained on Hitachi R-600 and JNM-FX-100 spectrometers using TMS as an internal standard. Unless otherwise stated, NMR data refer to deuteriochloroform solutions.

Aromatic aldoximes were prepared according to the conventional procedure. ${ }^{13)}$ Nitrogen dioxide was obtained from commercial source (Seitetsu Kagaku Co., Ltd., Osaka) and used without purification.

Preparation of (Dinitromethyl)arenes (2). To a solution of nitrogen dioxide $(20 \mathrm{mmol})$ in ether $(2 \mathrm{ml})$ chilled in ice was added a solution of aldoxime $(2 \mathrm{mmol})$ in ether $(10 \mathrm{ml})$. The blue reaction mixture immediately turned deep green and the liberation of gaseous product was observed. After standing for 30-60 min, when TLC monitoring showed completion of the reaction, the reaction mixture was evaporated under reduced pressure. The oily residue was taken up in ether, and the ethereal solution was extracted with $0.5 \mathrm{M}$ aqueous potassium hydroxide $\left(1 \mathrm{M}=1 \mathrm{~mol} \mathrm{dm}^{-3}\right)$ until the initial yellow aqueous phase became almost colorless. The combined alkaline extracts were saturated with sodium chlo- 
ride, made weakly acidic by the addition of hydrochloric acid, and extracted with ether. Evaporation of the former ethereal extract gave parent aldehyde and arenecarboxylic acid, while removal of the solvent from the latter ethereal extract afforded 2 and carboxylic acid. The product 2 was further purified by chromatography on silica gel using hexane-dichloromethane as the eluent.

Reaction of 9-Anthracenecarbaldehyde Oxime (3; R=H) with Nitrogen Dioxide. To a solution of nitrogen dioxide $(2.6 \mathrm{mmol})$ in dry ether $(1 \mathrm{ml})$ at $0^{\circ} \mathrm{C}$ was added dropwise a solution of 9-anthracenecarbaldehyde oxime $(0.058 \mathrm{~g} ; 0.26$ $\mathrm{mmol})$ in the same solvent $(15 \mathrm{ml})$. The resulting green mixture was stirred for $2 \mathrm{~h}$, allowing gradually to attain room temperature. After this time TLC monitoring showed complete disappearance of aldoxime. The solvent was removed together with nitrogen dioxide under reduced pressure and a yellow residue was taken up in chloroform and chromatographed on a silica gel column. Elution with chloroform gave 10-nitro-9-anthracenecarbonitrile oxide (7) as yellow crystals, $\mathrm{mp} 212-215^{\circ} \mathrm{C}$. Yield, $0.038 \mathrm{~g}(55 \%)$. ${ }^{1} \mathrm{H}$ NMR: $\delta=7.6-8.0(\mathrm{~m}, 6 \mathrm{H})$ and $8.3-8.5(\mathrm{~m}, 2 \mathrm{H})$; IR: 2275 , $1520,1310,1275,1255$, and $765 \mathrm{~cm}^{-1}$. Found: $\mathrm{C}, 67.67 ; \mathrm{H}$, $3.21 ; \mathrm{N}, 10.46 \%$. Calcd for $\mathrm{C}_{15} \mathrm{H}_{8} \mathrm{~N}_{2} \mathrm{O}_{3}: \mathrm{C}, 68.18 ; \mathrm{H}, 3.05 ; \mathrm{N}$, $10.60 \%$.

Further elution with methanol gave 9-anthracenecarboxylic acid as yellow crystals. ${ }^{14)}$ Yield, $0.020 \mathrm{~g} \mathrm{(35 \% ).}$

Reaction of 10-Methyl-9-anthracenecarbaldehyde Oxime (3; $\mathbf{R}=\mathrm{Me}$ ) with Nitrogen Dioxide. A suspension of aldoxime $(0.264 \mathrm{~g} ; 1.12 \mathrm{mmol})$ in dry ether $(20 \mathrm{ml})$ was stirred and a stream of nitrogen dioxide was slowly passed at $0-10^{\circ} \mathrm{C}$ until the reaction mixture turned to a blue clean solution. After standing for $1 \mathrm{~h}$ at room temperature, the mixture was diluted with water $(30 \mathrm{ml})$. Effervescence was followed by separation into two layers. The yellow organic phase was separated, dried with sodium sulfate, and evaporated under reduced pressure. A yellow oily residue was chromatographed on silica gel using hexane-dichloromethane $(1: 1)$ as the eluent to give 10-methyl-10-nitro-9-anthrone (10) as colorless crystals, $\mathrm{mp} 145-152^{\circ} \mathrm{C}$ (decomposition under

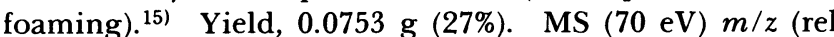
intensity) $253\left(\mathrm{M}^{+}, 1\right), 237$ (13), and 207 (100); ${ }^{1} \mathrm{H} N M R$ $\delta=2.33(\mathrm{~s}, 3 \mathrm{H})$ and $7.40-8.63(\mathrm{~m}, 8 \mathrm{H}) ;{ }^{13} \mathrm{C} \mathrm{NMR}: \delta=31.03$ (q), 88.94 (s), $125.76(\mathrm{~s}), 128.05$ (d), 130.09 (d), 134.42 (d), and 139.68 (s); IR: $1680,1600,1550,1340,1300$, and $940 \mathrm{~cm}^{-1}$. Found: $\mathrm{C}, 70.83: \mathrm{H}, 4.52 ; \mathrm{N}, 5.14 \%$. Calcd for $\mathrm{C}_{15} \mathrm{H}_{11} \mathrm{NO}_{3}$ : C, $71.14 ; \mathrm{H}, 4.38 ; \mathrm{N}, 5.53 \%$.

The minor product was identified as 9-methyl-10trinitromethylanthracene (11) by direct comparison with the authentic specimen obtained by the other route. ${ }^{2)}$

Nitration of (Dinitromethyl)benzene (2a). The reaction was carried out under various conditions. The typical results are shown below:

a) Compound 2a (0.614 g; $3.37 \mathrm{mmol})$ was dissolved into fuming nitric acid $(10 \mathrm{ml}, d=1.5)$ at $-20^{\circ} \mathrm{C}$ and the resulting mixture was left for $2 \mathrm{~h}$ at this temperature, then poured into brine $(300 \mathrm{ml})$. The organic phase was extracted with ether and the extract was evaporated to leave a yellow solid, which was recrystallized from hexane-dichloromethane to give $m$ nitrophenyldinitromethane $(\mathbf{2 g})$ as nearly colorless plates, mp $122-124^{\circ} \mathrm{C}$ (lit, ${ }^{7)} 127-129^{\circ} \mathrm{C}$ ). Yield, $0.665 \mathrm{~g} \mathrm{(87 \% ).}$ Found: $\mathrm{C}, 37.20 ; \mathrm{H}, 2.07 ; \mathrm{N}, 18.47 \%$. Calcd for $\mathrm{C}_{7} \mathrm{H}_{5} \mathrm{~N}_{3} \mathrm{O}_{6}$ : $\mathrm{C}$, $37.02 ; \mathrm{H}, 2.22 ; \mathrm{N}, 18.50 \%$.

Infrared and ${ }^{1} \mathrm{H} N \mathrm{NR}$ spectral inspection of the crude product mixture showed the absence of other important products.

When the reaction mixture was allowed to stand for several days at room temperature, TLC monitoring revealed the gradual accumulation of the second nitration product, which was easily separated from $\mathbf{2 g}$ by chromatography on silica gel and identified as $m$-nitrophenyltrinitromethane (12). Colorless prisms, mp $63-65^{\circ} \mathrm{C}\left(\right.$ lit, $\left.^{7)} 65^{\circ} \mathrm{C}\right) .{ }^{1} \mathrm{H}$ NMR: $\delta=7.86-7.97(\mathrm{~m}, 2 \mathrm{H})$ and $8.58-8.72(\mathrm{~m}, 2 \mathrm{H})$; IR: 1610,1575 , $1530,1350,1290,1225,870,840,800$, and $730 \mathrm{~cm}^{-1}$. Found: C, 30.96; $\mathrm{H}, 1.51 ; \mathrm{N}, 18.30 \%$. Calcd for $\mathrm{C}_{7} \mathrm{H}_{4} \mathrm{~N}_{4} \mathrm{O}_{8}: \mathrm{C}, 30.90$; $\mathrm{H}, 1.48 ; \mathrm{N}, 20.59 \%$.

Attempted nitration of $\mathbf{2 a}$ with fuming nitric acid in dichloromethane led to recovered substrate.

b) Compound 2a (0.099 g, $0.054 \mathrm{mmol})$ was dissolved into concentrated sulfuric acid $(5 \mathrm{ml})$ to yield a slightly yellow solution, to which fuming nitric acid $(5 \mathrm{ml})$ was added and the resulting mixture was left to stand for $2 \mathrm{~h}$ at room temperature. Quenching with water followed by usual work-up gave the expected product $\mathbf{2 g}$ in $78 \%$ yield. $\mathrm{Mp}$ $122-124^{\circ} \mathrm{C}$

The authors thank Advanced Instrumentation Center for Chemical Analysis, Ehime University, for ${ }^{13}$ C NMR determinations and elemental analyses.

\section{References}

1) The reaction of polysubstituted aromatics. Part LXIII; Part LXII: H. Suzuki, H. Koide, and T. Ogawa, Bull. Chem. Soc. Jpn., 61, 501 (1988).

2) H. Suzuki, E. Kimura, T. Katayama, and T. Ogawa, Chem. Lett., 1987, 979.

3) G. Ponzio, J. Prakt. Chem., 73, 494 (1906); Gazz. Chim. Ital., 36, II, 287 (1906).

4) Other preparative methods of limited scope include; a) Reaction of aryl halides with dinitromethanide ion: I. V. Tselinskii and G. I. Kolesetskaya, Zh. Org. Khim., 9, 2471 (1973). b) Reaction of arenes with iodonium dinitromethanide: V. V. Semenov, A. B. Bruskin, S. A. Shevelov, and A. A. Faizel'berg, Izv. Akad. Nauk SSSR, Ser. Khim., 1982, 2741. c) Electrolysis of tetraalkylammonium dinitromethanide in the presence of arenes: M. E. Niyazymbetov, V. A. Petrosyan, S. A. Shevelov, V. V. Semenov, and A. A. Faizel'berg, Izv. Akad Nauk SSSR, Ser. Khim., 1982, 2747.

5) M. Milone and A. Massa, Gazz. Chim. Ital., 70, 196 (1940).

6) L. F. Fieser and W. von E. Doering, J. Am. Chem. Soc., 68, 2252 (1946)

7) A. I. Titov and V. V. Smirnov, Dokl. Akad. Nauk SSSR, 83, 243 (1952).

8) L. I. Khmel'nitskii, S. S. Novikov, and O. V. Lebedev, Zh. Obshch. Khim., 28, 2303 (1958).

9) S. S. Novikov, L. I. Khmel'nitskii, and O. V. Lebedev, Zh. Obshch. Khim., 28, 2296 (1958); Izv. Akad. Nauk SSSR, Ser. Khim., 1960, 1783.

10) For a review of the chemistry of trinitromethyl compounds, See L. A. Kaplan, "The Chemistry of the Nitro and Nitroso Groups," part 2, ed by H. Feuer, Interscience, New York (1970), p. 289.

11) H. Wieland and L. Semper, Ber., 39, 2522 (1906). See also C. Grundmann, "Methoden der Organischen Chemie," Vol. 10/3, ed by E. Müller, 4th ed., Georg Thieme, 
Stuttgart (1965), p. 841.

12) H. Suzuki, H. Koide, and T. Ogawa, Bull. Chem. Soc. Jpn., 61, 501 (1988).

13) R. L. Shriner, R. C. Fuson, and D. Y. Curtin, "The Systematic Identification of Organic Compounds," 4 th ed.,
Maruzen, Tokyo (1957), p. 254.

14) P. D. Bartlett and F. D. Greene, J. Am. Chem. Soc., 76, 1088 (1954).

15) E. B. Barnett and J. W. Cook, J. Chem. Soc., 123, 2640 (1923). 